Annals of Tropical Research 30[1]:40-59 (2008)

(c) VSU, Leyte, Philippines

\title{
Altitudinal distribution of skinks along Cantubias Ridge of Mt. Pangasugan, Baybay, Leyte
}

\author{
Litlen P. Dapar and Teofanes A. Patindol \\ Department of Biological Sciences, College of Arts and Sciences and Department of \\ Forest and Wildlife Management and Conservation, College of Forestry and \\ Natural Resources, Visayas State University, Baybay City, Leyte
}

\begin{abstract}
The study was conducted to identify the species of skinks and to determine their distribution and abundance with special reference to elevation along Cantubias Ridge of Mt. Pangasugan. A preliminary survey was done in the two study areas to establish sites that represent the different altitude ranges from 40 to $500 \mathrm{~m}$ asl). Three $10 \mathrm{~m} \times 20 \mathrm{~m}$ quadrats were laid equidistant from one another in each elevation range. Sampling and collection of specimens were done at different times of the day (9:00 A.M., 12:00 noon, and 3:00 P.M.). Basic biometric measurements were taken from the caught specimens to aid in identification.

Seven species of lizards from the family Scincidae belonging to 4 genera were identified. It was observed that more species and individuals were present in the lower elevations than at higher elevations. Temperature and light intensity decreased as the elevation increased. More number of species and individuals were encountered at higher temperature and light intensity than at lower temperature and light intensity. Sphenomorphus jagori was the most abundant and most widely distributed species while $S$. variegatus was least abundant and restricted only to 301-400 m asl elevation range.
\end{abstract}

Keywords: : skinks, Mt. Pangasugan, altitude

Correspondence: T. A. Patindol Address: Department of Forest and Wildlife Management and Conservation, College of Forestry and Natural Resources, Visayas State University, Baybay City, Leyte 6521-A Philippines. E-mail: tapatindol@yahoo.com Tel. No. (053) 335-4210

DOI: $10.32945 /$ atr3014.2008 


\section{INTRODUCTION}

A forest ecosystem is a community of plants, animals, and microorganisms, and the physical environment they inhabit, in which trees are the dominant life form (Hunter, 1990). The height of trees, and thus of forests, produces considerable vertical stratification in terms of both the structure of the trees and the microclimate they create. Together, vertical stratification and an abundance of organic matter provide niches for a wealth of organisms, making forests an especially diverse ecosystem.

Forest harbors an enormous plant and animal biodiversity. It provides the basic habitat for a large proportion of the world's wildlife, including amphibians, reptiles, birds, and mammals (Young, 1982). However, due to habitat fragmentation, destruction, and other results of environmental modifications, some of the animal species, especially the rare ones, living in the forest are facing the dangers of being threatened and becoming endangered. As mentioned by Bolen and Robinson (1995), habitat modifications are the ultimate destroyers of wildlife and too often are the bases for the threatened status of plants and animals.

In the latest days of geologic history, Carr (1977) recognized about 6,000 species of reptiles scattered over the earth. From the standpoint of abundance and diversity, lizards and snakes are by far the most flourishing reptiles of today including about 750 genera and at least 5,700 species occurring in every continent except Antarctica. In the Philippines, Alcala (1980) found that the reptilian fauna is composed of about 90 species of lizards, 75 snakes, 2 or 3 land turtles, and 2 crocodiles. Of these 90 species of lizards, the skinks make up the largest family with 1,200 species (Uetz, 2003).

Skinks may be terrestrial, burrowing, or arboreal in habit (Alcala, 1986). Most are diurnal; some are nocturnal and crepuscular (Uetz, 2003). They are insectivorous but some are herbivorous or omnivorous.

Despite its diversity and abundance, lizards are one of the least studied animals in a forest ecosystem. Since many people tend to give more importance to organisms which are of economic value, they are found to be of less significance (Custodio, 1986). Although lizards are economically less significant, they are important in maintaining the balance of the ecosystem. Since lizards are largely insectivorous, they play an important role in keeping down the number of insects where some of which are man's competitors (Alcala, 
1980). So far, there are seemingly few significant contributions that deal with the investigation of skinks in Mt. Pangasugan. These were the work of Denzer et al. (1994), Milan and Margraf (1993) and Milan et al. (1995). However, these former herpetological studies concentrated mainly on determining the suitability of reptiles as indicator species.

This paper presents the distribution and abundance of the different species of lizards of the family Scincidae within different elevation gradients along Cantubias Ridge of Mt. Pangasugan.

\section{MATERIALS AND METHODS}

\section{Description of the study area}

Mt. Pangasugan is one of the peaks of the Central Cordillera of Leyte. It lies at the western boundary of an area of primary forest that is $150 \mathrm{~km}^{2}$ or more in extent (Heaney et al, 1989, as cited by Ceniza, 1995). It is situated $10^{\circ} 44^{\prime} \mathrm{N}: 124^{\circ} 48^{\prime} \mathrm{E}$ of the coastal city of Baybay, Leyte where at its foot is also located the Visayas State University (VSU). The western side of the mountain is composed of parallel ridges which descend gradually to the narrow alluvial plain. The northern and southern sides of the ridges are generally steep giving rise to the young rivers like Pangasugan, Lago-lago and Calbiga-rivers (Asio, 1994). Its geology is dominated by andesitic and basaltic pyroclastics ranging in age from the Pliocene to recent. They commonly occur as volcanic agglomerates and pyroclastic breccia referred to as Pangasugan formation. It lies west of the Philippine fault line that passes approximately at the center of Leyte (Asio and Jahn, 1995, as cited by Ceniza, 1995). The climate belongs to Type IV classification, which is characterized by more or less uniform distribution of rainfall throughout the year. The mean annual rainfall is 2,500 mm. Heavy rains come in November to January (Corona, 1920).

\section{Sampling and collection of specimens}

The sampling and collection of specimens were done along Cantubias Ridge (40-500 m asl). A preliminary survey in these study areas was conducted 
to establish representative sampling sites. Five (5) sampling sites along Cantubias Ridge were selected representing the different altitudinal ranges. The five sites were established as follows: Site 1: 40-100 m asl; Site 2: 101$200 \mathrm{~m}$ asl; Site 3: 201-300 m asl; Site 4: 301-400 m asl; Site 5: 401-500 m asl. The altitudes of the different sites were determined using an altimeter.

Three $10 \times 20 \mathrm{~m}$ quadrats were laid equidistant from each another, except in Sites 4 and 5 along Cantubias Ridge. Since the slope of the sites are very steep and the terrain is very rough, the three $10 \mathrm{~m} \times 20 \mathrm{~m}$ quadrats were laid out $10 \mathrm{~m}$ away from one another.

Since reptiles are said to be most active in the morning and early afternoon ( $0900 \mathrm{~h}$ to $1500 \mathrm{~h}$ ), the observation and collection of specimens were done at 9:00 A.M, 12:00 nn, and 3:00 P.M. Temperature and light intensity were determined using a thermometer and light meter, respectively. The forest floor within the quadrat was systematically and extensively searched for the presence of skinks. Special attention was given to areas where skinks are likely to be present such as fallen logs, tree holes, tree buttresses, bark, leaves, ferns, shrubs, rocks, moss, and vegetation debris. All the skink species encountered in each quadrat were identified and the number of individuals per species were counted. Since skinks are mobile, those individuals that move outside the quadrat were included. Information on the weather conditions, time of the day, and a description of the location (macro- and micro-habitat) where the lizards were caught were also noted (Haribon Foundation, 2001).

\section{Identification and measurement of specimens}

Once an individual was caught, it was quickly placed in a plastic bag with plenty of air and a little water. A detailed description of coloration and morphological characteristics were noted and biometrics were taken using calipers or rulers. Weight was determined with a pesola. The specimens were identified down to the species level by referring to pictures and species descriptions based on Alcala (1986) and www.arcbc.org/ph. A representative specimen of each species caught was taken and photographed. The specimen was killed by injecting $70 \%$ ethyl alcohol into the heart, properly labeled, fixed with formalin and preserved in alcohol (Haribon Foundation, 2001). The preserved specimens were deposited at the Natural History Museum, 
Visayas State University for further verification.

To provide uniformity in data collection, the following measurement procedure suggested by Brown and Alcala (1980), as cited by Custodio (1986), was used.

Measurements of specimens were made and determined to the nearest $0.1 \mathrm{~mm}$ using a caliper or ruler. Measurements were standardized as follows: (1) head length was measured from snout tip to the posterior of the ear opening; (2) for large eyes, eye diameter was measured by placing the caliper or ruler within the socket and under some pressure determining the anterior-posterior diameter; for small-eyes, the diameter was measured from the anterior to the posterior corner; (3) head breadth was measured at the widest point near angle of jaws. The measurements of other biometrics were taken from Haribon Foundation (2001).

Data measured included the following; snout-vent length, axilla-groin distance, hind limb length, head breadth, head length, snout length, ear diameter and eye diameter (Figure 1).

\section{Analysis of data}

The degree of similarity between elevation ranges was computed using Sorensen's Index of Similarity with the following formula:

$$
\begin{aligned}
& \begin{array}{c}
\text { Index of Similarity (Sorensen's Index) } \\
2 c \\
S=--- \\
a+b
\end{array}
\end{aligned}
$$

Where: $\quad a=$ no. of species in one site

$\mathrm{b}=$ no. of species in the other site

$\mathrm{c}=$ no. of species common to both sites 


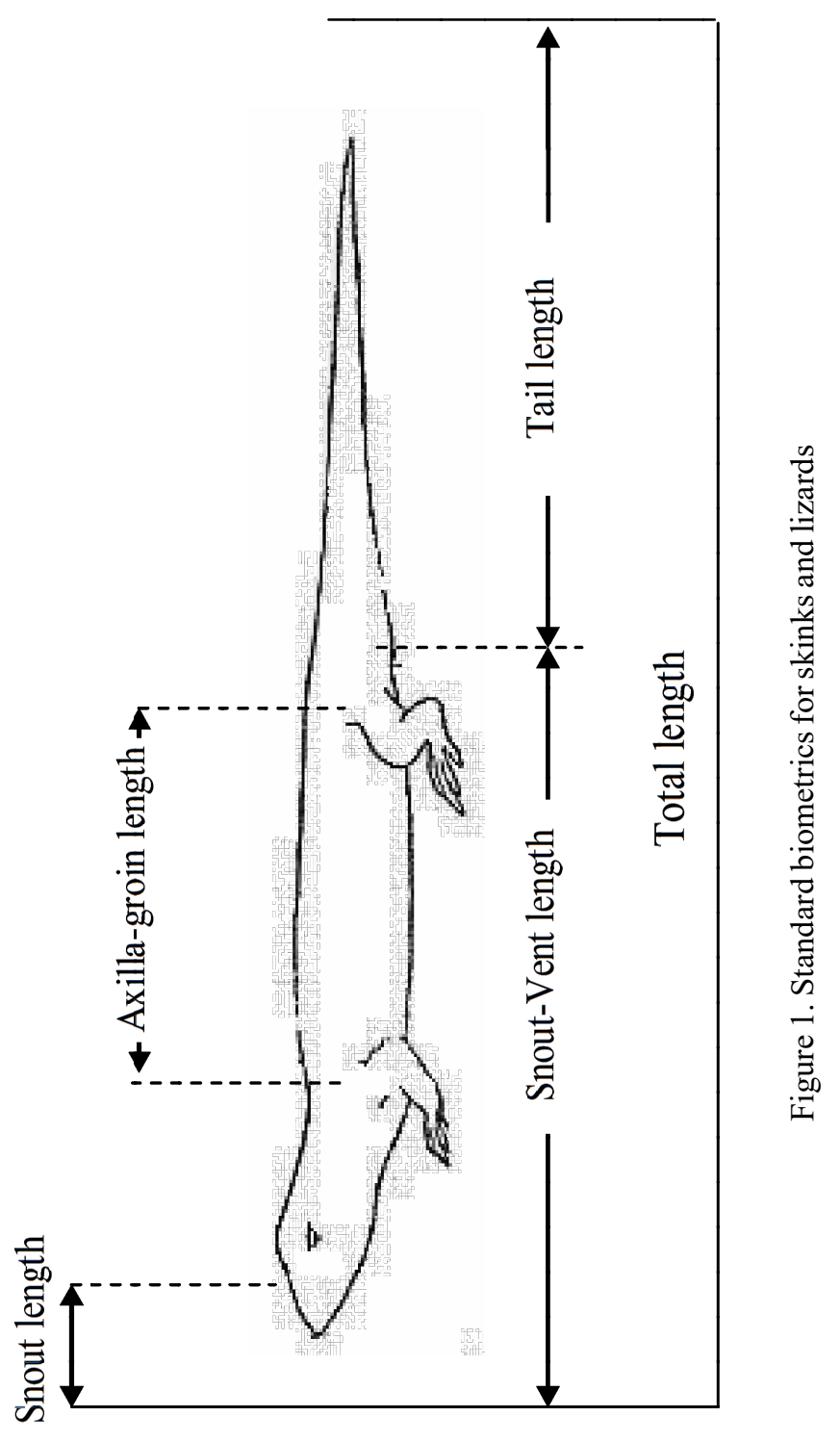




\section{RESULTS AND DISCUSSION}

\section{Species composition}

A total of 7 species of skinks in five genera were recorded along Cantubias Ridge. (Table 1). The genus Sphenomorphus was represented by Sphenomorphus jagori Peters (Jagor's Sphenomorphus), S. decipiens Boulenger (Black-sided Sphenomorphus), S. cumingi Gray (Cuming's Eared Skink), and S. variegatus Peters (Black-spotted Sphenomorphus). The genus Mabuya Fitzinger was represented by only 1 species, the Mabuya multicarinata Gray (Two-striped Mabuya). The rest of the genera, Lipinia Gray, Lamprolepis Fitzinger are each represented by a single species. They were Lipinia pulchella Gray (Yellow-striped Slender Tree Skink), and Lamprolepis smaragdina Mertens (Spotted Green Tree Skink), respectively.

Among the species collected, Sphenomorphus was the most represented genus with 4 species. The genera Lamprolepis, Mabuya, and Lipinia were the least represented genera with only 1 species each. The genus Sphenomorphus had the highest number of individuals encountered (139) while Lipinia was the least with only 4 individuals (Table 2).

Figure 2 shows the composition of skink species along Cantubias Ridge of Mt. Pangasugan. S. jagori constituted $59.57 \%$ of the total number of skinks found. This was followed by M. multicarinata (32.73\%). L. smaragdina and $S$. cumingi had the same percentage (2.27\%). L. pulchella and $S$.

Table 1. Species of skinks recorded along Cantubias Ridge of Mt. Pangasugan.

\begin{tabular}{lll}
\hline GENERA & SCIENTIFIC NAME & \multicolumn{1}{c}{ COMMON NAME } \\
\hline Lamprolepis & L.smaragdina & Spotted Green Tree Skink \\
Lipinia & L. pulchella & Yellow-striped Slender Tree Skink \\
Mabuya & M. multicarinata & Two-Striped Mabuya \\
Sphenomorphus & S. cumingi & Cuming's Eared Skink \\
& S. jagori & Jagor's Sphenomorphus \\
& S. decipiens & Black-sided Sphenomorphus \\
& S. variegatus & Black-spotted Sphenomorphus \\
\hline
\end{tabular}




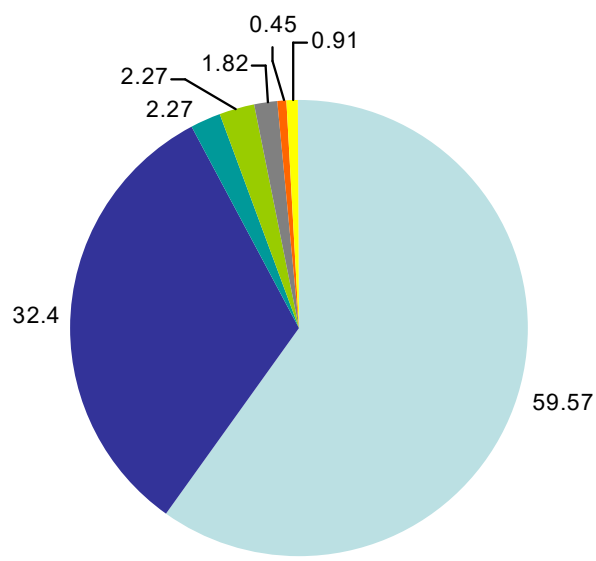

S. jagori

M. multicarinata

- L. smaragdina

S. cumingi

- L. pulchella

S. variegatus

S. decipiens

Figure 2. Composition of skink species along Cantubias Ridge of Mt. Pangasugan 
Table 2. Number of species and individuals per genera of skinks along Cantubias Ridge of Mt. Pangasugan

\begin{tabular}{lcc}
\hline GENERA & NUMBER OF SPECIES & NUMBER OF INDIVIDUALS \\
\hline Lamprolepis & 1 & 5 \\
Lipinia & 1 & 4 \\
Mabuya & 1 & 72 \\
Sphenomorphus & 4 & 139 \\
Total $------\frac{7}{7}---------\frac{1}{220}------$ \\
\hline
\end{tabular}

decipiens had $1.82 \%$ and $0.91 \%$, respectively. The species $S$. variegatus was the least contributor to the total number of skinks $(0.45 \%)$ found.

\section{Altitudinal distribution and abundance}

The distribution and the number of skinks at different elevation ranges are presented in Table 3. As shown in the table, $S$. jagori was the most widely distributed and most abundant scincid lizard along Cantubias Ridge of Mt. Pangasugan. It was found in all sampling sites, which were from $40 \mathrm{~m}$ asl up to $500 \mathrm{~m}$ asl. This only means that this species can tolerate a wide range of environmental conditions. There were a total of 131 individuals recorded along the ridge, where most of which were found at 101-200 $\mathrm{m}$ asl (42) and at 201$300 \mathrm{~m}$ asl (34). There were only 17 individuals encountered at $40-100 \mathrm{~m}$ asl and at 401-500 $\mathrm{m}$ asl. This somehow supports the findings of Denzer(1994), claiming that this species is restricted to primary and secondary forest with a dense canopy. S. jagori was still abundant at 101-200 $\mathrm{m}$ asl despite the fact that some parts are cultivated with agricultural crops. This can be attributed to the presence of some tree patches of good canopy cover which provide the area with shade, moist ground, and some available leaf litter to which this species is adapted.

The next widely distributed species is the slender arboreal skink, Lipinia pulchella. It could be found from $40 \mathrm{~m}$ asl up to $400 \mathrm{~m}$ asl., but with few number of individuals (4). This is somehow expected since this species is very sensitive to water loss and cannot survive in open, intensively used plantations or logged areas (Denzer, 1994). The presence of tree patches with still good 
Table 3. Distribution and abundance of skinks along the Cantubias Ridge of Mt. Pangasugan by elevation

\begin{tabular}{|c|c|c|c|c|c|c|}
\hline \multirow[b]{2}{*}{ Species } & \multicolumn{6}{|c|}{ ELEVATION $(\mathrm{m})$} \\
\hline & $40-100$ & $101-200$ & $201-300$ & $301-400$ & $401-500$ & No. \\
\hline Sphenomorphus jagori & 17 & 42 & 34 & 21 & 17 & 131 \\
\hline Lipinia pulchella & 1 & 1 & 1 & 1 & & 4 \\
\hline Mabuya multicarinata & 14 & 24 & 34 & & & 72 \\
\hline Sphenomorphus decipiens & 1 & 1 & & & & 2 \\
\hline Lamprolepis smaragdina & & 2 & 1 & 1 & 1 & 5 \\
\hline Sphenomorphus cumingi & & & 5 & & & 5 \\
\hline Sphenomorphus variegatus & & & & 1 & & 1 \\
\hline$\overline{T o t a l}------$ & 33 & 70 & 75 & $-\overline{24}$ & 18 & 230 \\
\hline rotal & 33 & 10 & 15 & 24 & 18 & $\angle 20$ \\
\hline
\end{tabular}

canopy cover at $40 \mathrm{~m}$ asl to $400 \mathrm{~m}$ asl allows this species to survive.

The species Mabuya multicarinata seemed to be associated with manmade habitats and were very well-adapted to open and sun-exposed areas. This species was found from $40 \mathrm{~m}$ asl up to $300 \mathrm{~m}$ asl along the Cantubias Ridge where most of the different plantations of coconut, abaca, banana, etc. are located. Some parts of the area were even dominated by grasses. These areas provide the kind of habitat that $M$. multicarinata prefers. Denzer et al. (1994) reported that this species requires open sunny patches where it can be encountered in high numbers. He added that it is most common in extensively used plantations with a mixture of ample decaying leaf litter and grass. It was also observed that this species was no longer found beyond the elevations of $300 \mathrm{~m}$ asl. This is because these areas are heavily shaded due to denser and thicker canopy cover.

Sphenomorphus decipiens was found between $40 \mathrm{~m}$ asl up to $200 \mathrm{~m}$ asl along Cantubias Ridge with only 2 individuals, which were seen near a rotting $\log$.

Lamprolepis smaragdina was found at $101 \mathrm{~m}$ asl up to $500 \mathrm{~m}$ asl along the Cantubias Ridge. Five individuals were found in areas dominated by coconut. According to Alcala (1986), coconut and garden trees in cultivated areas and various trees in the lowlands and natural vegetation types support the survival of this species.

Sphenomorphus cumingi was found only between 201-300 m asl with 5 individuals. It is in these areas where dipterocarp trees were mostly growing. 
This supports the observations of Brown and Alcala (1980), as cited by Denzer et al. (1994), that $S$. cumingi is a terrestrial species which prefers dipterocarp forests and secondary growth forest from 500-1000 $\mathrm{m}$ asl.

Sphenomorphus variegatus was found only from $300-400 \mathrm{~m}$ asl along Cantubias Ridge, where there is denser and thicker canopy cover. These conditions prevent light from the sun in penetrating down into the ground, hence giving the area more shaded and cooler condition. This is in accordance with the study of Denzer et al. (1994) where all of their specimens were observed next to small creeks and only in the more shaded parts of the stream bed.

The distribution and abundance of skinks in each elevation range along Cantubias Ridge of Mt. Pangasugan are presented in Figure 3. Four species with 33 individuals were found at $40-100 \mathrm{~m}$ asl, 5 species with 70 individuals at 101-200 m asl, 5 species with 75 individuals at 201-300 m asl, 4 species with 24 individuals at $301-400 \mathrm{~m}$ asl, and 2 species with 18 individuals at $401-500 \mathrm{~m}$ asl. There was an increase in the number of species and individuals at $101 \mathrm{~m}$ asl up to $300 \mathrm{~m}$ asl. After the subsequent rise, the number of species and individuals decreased as the elevation increased. The increase in the species and number of individual at $101 \mathrm{~m}$ asl-300 $\mathrm{m}$ asl along the ridge could be due to the availability of different kinds of habitats. These elevations are considered as ecotones or transition zones since these are located between disturbed (open) and undisturbed (close) areas. Because of this, species adapted to open and sun-exposed areas and those adapted to close and shaded areas can be found in these elevation ranges.

Those who made investigations about the altitudinal distribution of skinks have different views. In his work on the skinks of Mt. Makiling, Taylor(1922b), as cited by Custodio (1986), found that S. decipiens, L. pulchella, and L. smaragdina are lowland forms. Custodio (1986), on the other hand, found S. decipiens up to $800 \mathrm{~m}$ asl in Mt. Makiling. However, the present study showed that S. decipiens and L. pulchella. are, indeed, lowland forms. The observation of Brown and Alcala (1980), as cited by Custodio (1986), regarding the species $S$. cumingi found between $500-1000 \mathrm{~m}$ asl was inconsistent with the author's observation. S. cumingi was found between 201-300 m asl. This inconsistency could be due to the presence of dipterocarp 


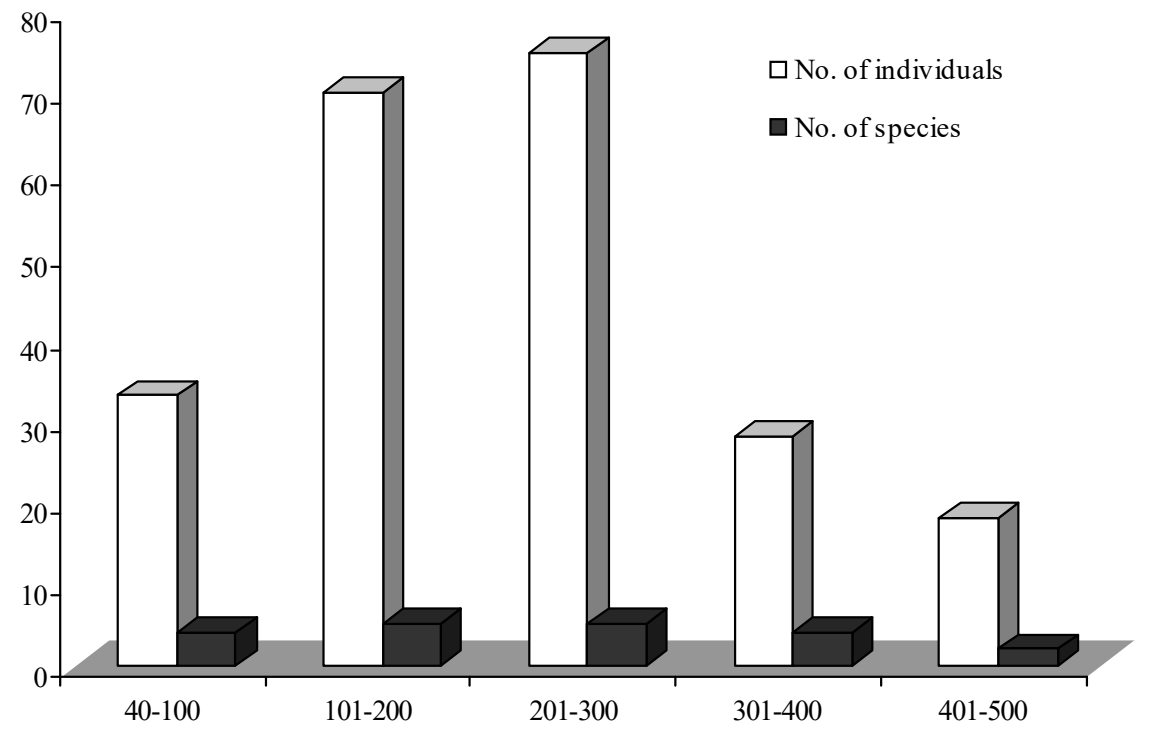

Figure 3. Distribution and abundance of skinks along Cantubias Ridge of Mt. Pangasugan per elevation 
trees at 201-300 m asl in Mt. Pangasugan. Custodio (1986) found his specimens of S. cumingi between 100-600 m asl. Denzer et al. (1994) found this species between 200-300 m asl. Their observations on the altitudinal distribution of $S$. jagori and M. multicarinata were generally consistent with the data obtained from this study. That of $S$. variegatus however, could not be verified since there are no data available to make comparisons. Although Denzer et al. (1994) found these species, they did not mention the elevations where the specimens were collected.

\section{Distribution and abundance of skink species in relation to} atmospheric condition of the sites

The data on temperature and light intensity are given in Table 4. Based on the results, these parameters were lower in the higher elevations compared to those in the lower elevations. In the Philippines, air temperature at high altitudes such as on the tops of high mountain peaks are lower than to those in the lowlands (Alcala, 1980). At high altitudes, the temperature decreases and humidity increases brought about by overhanging clouds that reduce the sun's burning rays (Chin, 1987).

Along the Cantubias Ridge, temperature and light intensity recorded at $40 \mathrm{~m}$ asl up to $300 \mathrm{~m}$ asl $\left(26.3^{\circ} \mathrm{C}-27.3^{\circ} \mathrm{C}\right.$ and $\left.78.0 \mathrm{lux}-533.7 \mathrm{lux}\right)$ were generally higher than those at $301 \mathrm{~m}$ asl up to $500 \mathrm{~m}$ asl $\left(23.5^{\circ} \mathrm{C}-24.2^{\circ} \mathrm{C}\right.$ and 24.0 lux - 33.9 lux). This can be explained by the presence of a denser

Table 4. Temperature $\left({ }^{\circ} \mathrm{C}\right)$ and light intensity (lux) at different elevation along Cantubias Ridge of Mt. Pangasugan

\begin{tabular}{lcc}
\hline Elevation $(\mathrm{m})$ & \multicolumn{2}{c}{ Parameters } \\
\cline { 2 - 3 } & Temperature $\left({ }^{\circ} \mathrm{C}\right)$ & Light Intensity (lux) \\
\hline $40-100$ & $26.3^{*}$ & 78.0 \\
$101-200$ & 27.7 & 736.0 \\
$201-300$ & 27.3 & 533.7 \\
$301-400$ & 24.2 & 24.0 \\
$401-500$ & 23.5 & 33.9 \\
\hline
\end{tabular}

*Values are the average of the readings taken at the different elevations. 
and thicker canopy cover at 301-500 $\mathrm{m}$ asl. Dense canopy cover prevents sunlight from penetrating down into the forest floor. As revealed by Chin (1987), humidity is always high, light level is low, and air movement is little or none under the forest canopy. In addition, anthropogenic disturbance is lesser at higher elevations than at the lower. Most of the areas in the lowlands are subjected to slash-and-burn farming. Areas from $101 \mathrm{~m}$ asl up to $300 \mathrm{~m}$ asl, where the highest temperature and light intensity range were recorded, are usually dominated by grasses and are planted with agricultural crops such as coconut (Cocos nucifera), camote (Ipomoea sp.), abaca (Musa textilis) and banana (Musa sapientum), takudo (Xanthosoma sp.) and other crops. It was also noticed that temperature and light intensity readings at the lowest elevation range of 40-100 $\mathrm{m}$ asl, were lower compared to those at $101-300$ $\mathrm{m}$ asl. This difference could be due to the presence of trees although the canopy cover is not as thick as that at $301-500 \mathrm{~m}$ asl. This area is still part of the VSU Forest Reserve.

Temperature and light intensity could have contributed to the distribution and abundance of skinks (Figures 4). Along the Cantubias Ridge, the highest temperature $\left(27.3-27.7^{\circ} \mathrm{C}\right)$ and light intensity ranges $(533.7-736.4$ lux $)$ were recorded at $101 \mathrm{~m}$ asl up to $300 \mathrm{~m}$ asl. It was in these elevation ranges where skinks were more concentrated in terms of species number and population. The elevation range $401-500 \mathrm{~m}$ asl where temperature $\left(23.5^{\circ} \mathrm{C}\right)$ and light intensity ( 33.3 lux) were the lowest, contained the least number of species and individuals. Based on the figure, more species and individuals were found in areas where temperature and light intensity were high than those areas with low temperature and light intensity. This is because reptiles (skinks) are ectothermic animals. They need light coming from the sun to carry its metabolic activities. Hence, skinks prefer to live in areas with high temperature and light intensity.

The study conducted by Alcala (1980) on the responses of lizards to high temperatures showed that $S$. jagori had rapid respiratory rates, difficulty in escape movements and paralysis of hind limbs at $33^{\circ} \mathrm{C}-35^{\circ} \mathrm{C}$. The same effects were observed in Mabuya multifasciata at temperatures of $39.9^{\circ} \mathrm{C}$ to $42^{\circ} \mathrm{C}$. Lamprolepis smaragdina also showed similar effects at $38^{\circ} \mathrm{C}$ to $40^{\circ} \mathrm{C}$. The responses of other skink species to temperature, however, are not known since no other study on this aspect has been conducted. 


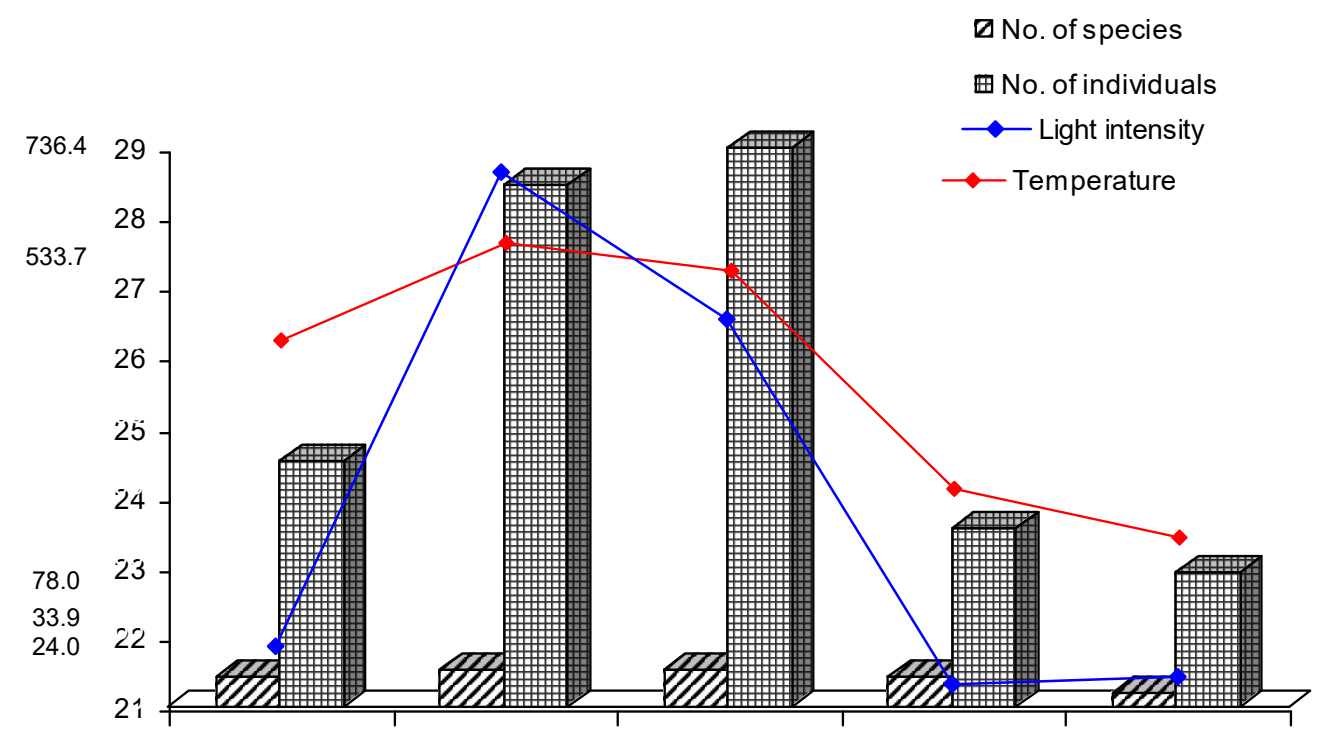

Figure 4. Distribution and abundance of skink species in relation to temperature $\left({ }^{\circ} \mathrm{C}\right)$ and light intensity (lux) along Cantubias Ridge of Mt. Pangasugan 


\section{Degree of similarity}

Using Sorensen's similarity coefficients (Tables 5), it was found that sampling Sites 1 and 2 in Cantubias Ridge were the most similar (0.89) in terms of skink species composition. Out of 7 species, 4 were common to both sites. Sites 1 and 3 ranked second (0.67) in terms of species composition where 3 species were found common to both sites. Sites 1 and 5 were the least similar (0.33) because only 1 species was common to both sites.

It was 'observed that the farther the sites are from each other in terms of elevation, the lower is the similarity index. Po (2002) reported that similar or closely similar sites are those that lie side by side or nearer in the low altitudes while those sites nearer in the higher altitudes were least similar.

Table 6 revealed the species common to both sites which were used in the calculation of similarity of coefficients. It was found that $S$. jagori, $S$. decipiens, L. pulchella and M. multicarinata were common to Sites 1 and 2. Species such as $S$. jagori and L. smaragdina were common to Sites 4 and 5. S. cumingi and S. variegatus could only be found in Sites 2 and 3, respectively. The only skink species found common in all sampling sites was S. jagori.

From the above results, it was evident that sites which were adjacent to one another had high similarity indices, which could be attributed to the similarity of their habitats. This supports the general observation that those species with the same habitat preference are likely to occur in the same sites. Low similarity indices between sites which are far from one another can also be explained by the high degree of habitat differences. Aside from this, the result also suggests that while some species are widely distributed along elevation gradients, some tend to be uniquely associated with a particular elevation range. Species like $S$. cumingi and $S$. variegates which are of limited range are highly sensitive, thus should be accorded with utmost attention in the conservation arena.

\section{CONCLUSIONS AND RECOMMENDATIONS}

Based on the results of the study, it can be concluded that while some species are widely distributed along different elevation gradients, some tend to be associated with a particular elevation range. S. jagori was found to be 
Table 5. Index of similarity of skinks (Sorensen's Measure) along Cantubias Ridge of Mt. Pangasugan

\begin{tabular}{cccccc}
\hline Site & 1 & 2 & 3 & 4 & 5 \\
\hline & & $4^{*}$ & 3 & 2 & 1 \\
2 & $0.89^{*}$ & & 4 & 3 & 2 \\
3 & 0.67 & 0.80 & & 3 & 2 \\
4 & 0.50 & 0.67 & 0.67 & & 2 \\
5 & 0.33 & 0.57 & 0.57 & 0.67 & \\
\hline
\end{tabular}

* Numbers above 1 are the species of skink common to both sides; numbers below 1 are the values of the Index of Similarity

* Site 1: 40-100 m asl; Site 2: 101-200 masl; Site 3:201-300 m asl; Site 4: 301-400 m asl; Site 5: 401-500 m asl

Table 6. Occurrence of skink species in the five sampling sites along Cantubias Ridge of Mt. Pangasugan

\begin{tabular}{llllll}
\hline \multirow{2}{*}{ Species } & \multicolumn{5}{c}{ Site } \\
\cline { 2 - 6 } & 1 & 2 & 3 & 4 & 5 \\
\hline S. jagori & $\mathrm{X}$ & $\mathrm{X}$ & $\mathrm{X}$ & $\mathrm{X}$ & $\mathrm{X}$ \\
S. cumingi & - & - & $\mathrm{X}$ & - & - \\
S. variegatus & - & - & - & $\mathrm{X}$ & - \\
S. decipiens & $\mathrm{X}$ & $\mathrm{X}$ & - & - & - \\
L. pulchella & $\mathrm{X}$ & $\mathrm{X}$ & $\mathrm{X}$ & $\mathrm{X}$ & - \\
M. multicarinata & $\mathrm{X}$ & $\mathrm{X}$ & $\mathrm{X}$ & - & - \\
L. smaragdina & - & $\mathrm{X}$ & $\mathrm{X}$ & $\mathrm{X}$ & $\mathrm{X}$ \\
\hline
\end{tabular}

* Site 1: 40-100 m asl; site 2: 101-200 m asl; site 3: 201-300 m asl; site 4: 301-400 m asl; site 5: $401-500 \mathrm{~m}$ asl

* x, present; -, absent 
the most widely distributed and abundant skink along Cantubias Ridge of Mt. Pangasugan. S. variegatus was least abundant and restricted only to 301400 elevation range. It can also be concluded that more species and individuals can be found at lower elevations, where habitat heterogeneity was high due to varying degree of disturbance, than at higher elevations which are predominantly secondary forests.

It is therefore recommended that areas which support skink species associated with man-made habitats should be maintained. Preservation of large tracts of primary forest along elevational gradients for conservation is fully recommended. In case of habitat destruction or change in the landscape of the mountain, a follow-up inventory should be done to keep record on the status of the threatened and rare species.

It can also be concluded that temperature and light intensity limit the altitudinal distribution of skinks in Mt. Pangasugan. There were more number of species and individuals recorded in higher temperature and light intensity than at lower temperature and light intensity. However, the optimum temperature and light intensity where skinks can still survive is not clear. Hence, it is also recommended that studies concerning the optimum temperature and light intensity that allows the survival of skinks should be conducted. Humidity, rainfall, and precipitation should also be included when taking the atmospheric conditions of the sites.

\section{LITERATURECITED}

ALCALA, A.C. 1980. Philippine Land Vertebrates. New Day Publishers, Manila. pp. $55-59$

ALCALA, A.C. 1986. Guide to Philippine Flora and Fauna. Amphibians and Reptiles. Natural Resource Management Centre, Ministry of Natural Resources and the University of the Philippines, Manila, Philippines. Vol. X. pp. 88-123.

Al-Johany, A. M., M. K. Al-Sadoon, and S. A. Al-Farraj. 1997. Reproductive biology of the skink, Scincus mitranus (Anderson 1871) in the Central region of Saudi Arabia. Journal of Arid Environment. 36 (2): 319-326.

ASEAN REGIONAL CENTER FOR BIODIVERSITY CONSERVATION (ARCBC). www.arc.org/ph. 
ASIO, V.B. 1994. The geology, geomorphology, and soils of Leyte. In: Tropical Ecology Seminar, Visca, Baybay, Leyte (April, 1994).

BALETE, D. S., H. C. MIRANDAJR., L. R. HEANEY, and J. F. RIEGER. 1992. Diversity and conservation of Philippine land vertebrates. An annotated biography. Silliman Journal 36 (1): 129-149.

BOLEN, E.G. and W. L. ROBINSON. 1995. Wildlife Ecology and Management. Prentice Hall, Inc. 512 pp.

BROWN, R. M. and A. C. DIESMOS. 1995. The lizard genus Luperosaurus: taxonomy, history and conservation prospects for some of the world's rarest lizards. Sylvatrop Tech. J. of Philipp. Ecosystems and Nat. Res. 10 (11 and 12): 107-124.

CARR, A. 1977. The Reptiles. Time-Life books, Inc., USA. 169 pp.

CENIZA, M. J. C. 1995. Arthropod abundance and diversity in different ecosystems of Mt. Pangasugan, Baybay, Leyte, Phil. with special reference to Coleoptera and Hymenoptera Fauna. Plits. 13 (3). pp. 9.

CHIN, W.Y. 1997. Ferns of the Tropics. Times Editions. Singapore. 190 pp.

CORONA, J. 1920. The Climate and Weather of the Philippines. Bureau of Printing. Manila. p. 189

CUSTODIO, C. C. 1986. Altitudinal distribution of lizards of the family Scincidae in Mt. Makiling, Laguna. Sylvatrop Philip. For. Res. J. 11(3 and 4): 181-202.

DENZER, W., K. HENLE, M. GAULKE, J. MARGRAF and P.P. MILAN. 1994. Annotated checklist of the reptiles and amphibians of Leyte, Philippines, with notes on their ecology and conservation. Annals of Tropical Research. 16 (4): 4 pp.

DENZER, W. 1994. Spatial organization among Scincid Lizards on Santubong Peninsula, Sarawak, Borneo. In: South-east Asian Island Ecosystems Workshop and Seminar Lecture Notes. Visca, Baybay, Leyte. pp 40-44.

DICKERSON, R.I. 1928a. Distribution of Life in the Philippines. The Bookmark, Inc., Manila. $322 \mathrm{pp}$.

GROLIER ENCYCLOPEDIAOF KNOWLEDGE. 1995. Skink. Grolier Incorporated. Vol.17. pp. 108.

HARIBON FOUNDATION. 2001. Guidelines for Amphibian and Reptile Surveys. Diliman, Quezon City.

HUNTER, M.L., JR. 1990. Wildlife, Forests, and Forestry. Principles of Managing Forests for Biological Diversity. Prentice-Hall, NJ. 370 pp. 
MAGURRAN, A.E. 1988. Ecological Diversity and Its Measurement. Chapman and Hall. Princeton University, US. 167 pp.

MILAN, P.P. and J. MARGRAF. 1993. Amphibia and Reptilia of Mt. Pangasugan. Ecology Update No. 1. ViSCA-GTZ Program on Applied Tropical Ecology. ViSCA, Baybay, Leyte. p. 20.

MILAN, P.P., J. MARGRAF, K. HENLE and W. DENZER. 1995. Amphibia and Reptilia of Mt. Pangasugan. Ecology Update No.2. ViSCA-GTZ Program on Applied Tropical Ecology. ViSCA, Baybay, Leyte. p. 22.

PERRY, G. and D. W. BUDEN. 1998. Ecology, behavior and color variation of the green tree skink, Lamprolepis smaragdina (Lacertilia: Scincidae), in Micronesia. Micronesica. 31(2): pp. 263-273.

PO, P.M. 2000. The altitudinal distribution and diversity of monocotyledonous vegetation of Mt. Pangasugan, Baybay, Leyte. MS Thesis, UPLB.

UETZ, P. 2003. Skink - The Family Scincidae.http://www.emblheidelberg.de/uetz/families/ scincidae.htm/003. Accessed March 20, 2003.

WILES, G. J., G. H. RODDA, T. H. FRITTS and E.M. TAISACAN. 1990. Abundance and habit use of reptiles on Rota, Mariana Islands. Micronesia. 23(2): 153-166pp.

WILES, G. J., A. B AMERON JR. and R. E. BECK, JR. 1989. Notes on the herpetofauna of Tinian, Mariana Islands. Micronesia. 22 (1): 107-118pp.

YOUNG, R. A. 1982. Introduction to Forest Science. John and Wiley Sons. pp. 370-380. 